Journal of Qualitative Criminal Justice \& Criminology

\title{
Variations in Patrol \\ Officers' Concerns About \\ Racial Profiling Across \\ Communal Contexts
}

\section{Paul Reck ${ }^{1}$}

${ }^{1}$ Ramapo College

Published on: Aug 15, 2020

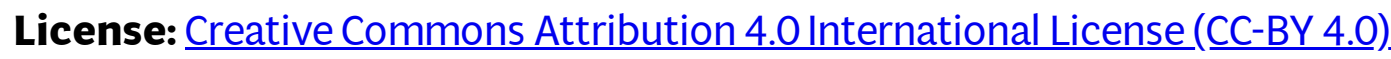




\section{ABSTRACT}

Numerous studies have explored the issue of racial profiling, but only a few studies have examined how officers view racial profiling and whether such views affect officers' patrolling of racial minorities. These latter studies generally have found that officers rationalize and dismiss the issue of profiling. However, studies pertaining to citizens' perceptions of the police and studies identifying policing imperatives that officers associate with particular spaces suggest that there are characteristics of communities that may play an important role in shaping officers' perceptions of profiling and patrolling of racial minorities. The current study, which is based on ethnographic ride-along interviews with and observations of 52 officers in three demographically different suburban communities in a northeastern state, examines how particular community contexts affect officers' views of racial profiling, and whether the salience of racial profiling as an issue constrains officers' patrolling of various racial minority groups. The author finds that officers' perceptions of racial profiling and patrolling of racial minorities vary by race and space across and within towns. Community-based constituency pressures, residential and school-related spatial arrangements, and perceptions of what racial minorities are doing in particular spaces appear to play a significant role in shaping the saliency of profiling concerns, and in turn, officers' patrolling of racial minorities.

\section{Introduction}

The issue of racial profiling, which refers to police officers' targeting and stopping of individuals primarily or exclusively based on perceived racial group status rather than individualized suspicion, has garnered substantial attention over the past two decades. - Although there is a significant body of research that has examined whether racial disparities in police stops and arrests are attributable to racial profiling, and a growing number of studies are available that investigate citizens' perceptions of being racially profiled, only a handful of researchers have addressed how officers view and respond to the issue of racial profiling. While heightened public attention to racial profiling appears to have contributed to police officers' greater sensitivity to accusations of such profiling (Miller, 2007), the limited research on officers' perceptions of profiling does not clearly establish whether such sensitivity acts as a constraint on officers' policing of racial minorities. The few studies exploring officers' perceptions of profiling generally suggest that officers rationalize and dismiss the issue of racial profiling, but these studies do not address why some officers do not dismiss the issue; the research does not elaborate on why many officers appear to do so and does not examine whether, and if so, how, officers' perceptions of racial profiling affect their actual patrolling of minorities. The current study, which examines officers' perceptions of racial profiling in three suburban communities, builds on a few citizen perception studies that imply that officers' perceptions and approaches toward racial minorities are shaped by neighborhood or communal context (e.g., Weitzer, 2000). The extant study 
directly investigates how different communal contexts affect how officers think about racial profiling and patrol racial minorities.

\section{Literature review}

Two important overall trends emerge from the limited number of studies that have examined how officers view the issue of racial profiling. First, while only a minority of officers appear to express concern about potential accusations of racial profiling (Bornstein, Charles, Domingo, \& Solis, 2011), the majority of officers indicate some awareness of such accusations due to extensive media coverage of some profiling cases (Heumann \& Cassak, 2007; Satzewich \& Shaffir, 2009). Second, regardless of whether officers appear to express concern about profiling accusations, a majority of officers engage in some type of rationalization of their policing of people of color that effectively neutralizes any potential concerns about profiling. $\stackrel{2}{=}$

How officers dismiss the issue of racial profiling (or potential accusations of profiling) via rationalizations depends on whether or not officers acknowledge differential policing of racial minorities. Some officers make egalitarian-based rationalizations, which argue that police treat racial minorities and Whites the same. Other officers acknowledge that they disproportionately patrol racial minorities, but rationalize that such disproportionality is justified.

Many egalitarian-based rationalizations focus on the attitudes and behaviors of individual officers. For instance, some of the officers in Bornstein et al.'s (2011) study invoked color-blind rationalizations, claiming that they and other officers "don't see race or color," show respect and fairness, and engage in no discrimination (p. 12). Officers in Glover's (2007) study emphasized that they focused on Whites who were out of place in non-White spaces to argue that they treated all people who were "out of place" the same.

Rather than emphasizing color-blindness, egalitarian-based rationalizations invoking the ethos and practices of police organizations stress a sensitivity to racial diversity. Officers in Satzewich and Shaffir's (2009) study dismissed the possibility of profiling by noting that their police department was intolerant of prejudice and committed to diversity through its multicultural recruiting (pp. 215-216). Officers suggested that such a diverse and sensitized workforce precluded officers from treating racial minorities different from Whites.

A third subset of egalitarian-based rationalizations focuses on the motives of police critics. Some officers in both Bornstein et al.'s (2011) and Satzewich and Shaffir's (2009) studies suggest that those who accuse the police of racial profiling are reverse racists who have negative attitudes toward the police. Officers in these latter studies also contend that police critics play the race card (Satzewich \& Shaffir, 2009) in order to either deflect attention away from their own wrongdoings (Satzewich \& Shaffir, 2009), or to take out their problems or failures on the police (Bornstein 2011). Like the 
aforementioned color-blind rationalizations, blaming police critics implies that the unjustly maligned officers treat everyone fairly and equally.

Unlike egalitarian-based rationalizations, most other rationalizations directly or implicitly acknowledge that officers disproportionately patrol racial minorities, but argue that such disparate policing is justified. These non-egalitarian rationalizations fall under three interrelated subcategories that respectively focus on (a) the behavior of racial minorities; (b) the appropriateness and effectiveness of law enforcement; or (c) the features and demographics of areas and characteristics of specific cases.

Under the first subcategory, officers contend that they stop and arrest racial minorities more than Whites because racial minorities commit a disproportionate percentage of crimes (Barlow \& Barlow, 2002; Bornstein et al., 2011; Heumann \& Cassak, 2007; Satzewich \& Shaffir, 2009). This presumed criminality rationalization places blame squarely on individual racial minorities, suggesting that they are responsible for any disproportionate policing outcomes.

Linked in part to the assumption of the first subcategory, the second subcategory focuses on racial profiling as good and necessary law enforcement (Barlow \& Barlow, 2002; Harris, 2002; Satzewich \& Shaffir, 2009). Some officers view racial profiling as appropriate (Barlow \& Barlow, 2002, p. 337) and effective enforcement (Harris, 2002; Heumann \& Cassak, 2007) based on the implicit assumption that racial minorities commit a disproportionate amount of crime. Instead of alluding to demographic crime patterns as the basis for effective law enforcement, other officers emphasize that the nature of police work itself forces officers to stereotype and discriminate. For these latter officers, racial profiling is synonymous with criminal profiling, such that profiling amounts to professional conduct (Satzewich and Shaffir, 2009).

In contrast to the first subcategory's emphasis on the criminal propensities of Blacks \& Latinos, $\frac{3}{-}$ the third subcategory of rationalizations implies that officers just happen to have more encounters with Blacks and Latinos based on the areas in which they disproportionately live, demographic probabilities of encounters, and the characteristics of specific descriptions of suspects. Some officers explain away officers' disproportionate encounters with racial minorities by arguing that such encounters are more likely because racial minorities disproportionately live in high crime neighborhoods (Bornstein et al., 2011:15) or problematic areas (Satzewich \& Shaffir, 2009). Other officers rationalize that disproportionate encounters with minorities are simply due to the available pool of people within a patrol area (Bornstein et al.). These officers contend that it is reasonable to have a greater percentage of encounters with racial minorities in areas disproportionately populated by racial minorities (Satzewich \& Shaffir, 2009). Similarly, some officers dismiss profiling accusations by arguing that officers are just stopping racial minorities who fit the description of a suspect (Bornstein et al., 2011). 
Rather than demonizing racial minorities, all of the third subcategory rationalizations treat disproportionate encounters with racial minorities as detached statistical probabilities.

There are a number of variables that appear to affect whether or not officers rationalize and hence dismiss racial profiling as an issue. At the individual level, officers' personal and vicarious experiences can preclude any rationalizations of profiling. Black and Latino officers who claim that they have been victims of profiling generally do not rationalize/dismiss the issue of profiling (Barlow \& Barlow, 2002; Bornstein et al., 2011; Harris, 2002). Some officers of all races who claim to have observed other officers engage in profiling or treat Whites more leniently also are highly unlikely to rationalize such profiling (Bornstein et al., 2011).

While individual-level variables dealing with officers' profiling-related experiences may play a role in whether or not officers rationalize racial profiling, the unanimous denials/rationalizations of profiling by all officers of color and White officers alike in Glover's (2007) and Satzewich and Shaffir's (2009) studies, and by the majority of officers of color and White officers in Bornstein et al.'s (2011) study suggest that structural variables play more of a significant role than individual-level variables do. Some of these structural variables pertain to police organizational policies and procedures, whereas others relate to the perceived characteristics of communities.

One organizational structural variable that appears to affect whether or not officers rationalize profiling is a department's deployment policy. Officers who are deployed to urban minority neighborhoods where drug and other criminal activity is more visible are more likely to rationalize profiling as being effective law enforcement (Barlow \& Barlow 2002).

Officers' rationalizations of profiling also appear to be influenced by a police organization's incentive structure. According to Barlow and Barlow (2002) and Harris (2002), police departments in recent decades have rewarded officers with pay increases, commendations, desirable assignments, and promotions for making high numbers of drug arrests. Officers who perceive that it is easier to go after Blacks and Latinos in making such arrests are more likely to rationalize that their livelihoods and career advancement depend on such arrests.

Apart from incentive structures, organizational pressures and officers' relative lack of power appear to contribute to officers' rationalizations and dismissals of profiling. Barlow and Barlow (2002) contend that officers engage in various rationalizations of their disproportionate stops and arrests of racial minorities because of pressures from superiors and the majority of the public to make such stops and arrests. Satzewich and Shaffir's (2009) finding that officers' denials of and rationalizations for their policing of racial minorities were learned through immersion in a police subculture implicitly suggests that officers faced pressure to conform to certain organizational cultural norms. Duran (2009a) argues that regardless of any perceived pressures, officers' lack of structural power to alter 
their deployment and crime prevention tasks further contributes to officers' dismissals of racial profiling.

Notwithstanding the influence that organizational-based structural variables may have in shaping whether officers rationalize racial profiling, a body of literature on race and policing suggests that communal-based structural variables may play a particularly influential role. Symbolic interactionist studies have identified the different meanings officers assign to different communal spaces, e.g., safe spots and danger spots (Werthmann \& Piliavin, 1967); structural, ecological-based macro-level studies have revealed that officers make distinctions between neighborhoods and communities based on configurations of race and class, as well as perceived rates of crime (Alpert \& Dunham, 1988; Smith, Visher, \& Davidson, 1984; Weitzer \& Tuch, 2006). A number of studies examining racial profiling suggest that officers' perceptions of how communal spaces are structured play a an important role in determining whether officers rationalize/ dismiss racial profiling as an issue (e.g., Bornstein et al., 2011; Duran, 2009a, 2009b; Goldsmith, Romero, Rubio-Goldsmith, Escobedo, \& Khoury, 2009; Romero, 2006; Solis, Portillos, \& Brunson, 2009; Vera Sanchez \& Adams, 2011). These latter studies, but most notably Bornstein et al. (2011), implicitly indicate that where officers perceive that there is some critically important law enforcement or community-related imperative associated with a particular communal space (e.g., neighborhood), such imperative overrides or trumps any competing concerns about racial profiling. Officers appear to be more likely to rationalize/dismiss racial profiling within a communal space where there is an imperative dealing with violent crime (Bornstein et al., 2011; Solis et al., 2009); gangs (Duran, 2009a, 2009b; Solis et al., 2009; Vera Sanchez \& Adams 2011); illegal drug activity (Barlow \& Barlow, 2002; Harris, 2002); illegal immigration (Goldsmith et al., 2009; Holmes, 1998; Romero, 2006; Solis et al., 2009); and gentrification or urban renewal (Romero, 2006; Vera Sanchez and Adams, 2011). Officers' racialization of communal spaces marked by or associated with a particular imperative (e.g., that a gang area is a Black or Latino area) further contributes to the rationalization/dismissal of racial profiling in such spaces (Solis et al., 2009). These imperatives seem to provide a basis on which officers can rationalize away disproportionate policing of racial minorities without experiencing any sense of ambivalence. When faced with such pressing imperatives in particular spaces, any concerns that officers may have about profiling appear to be eclipsed.

While the policing imperative framework provides an important communal/spatial basis for understanding why officers may rationalize/dismiss the issue of racial profiling, this is a static model that assumes that we should see the same phenomenon in every similarly structured space. For instance, officers should similarly rationalize/dismiss profiling as an issue in every high crime space. However, there are some studies, particularly those examining citizens' perceptions of police (Holmes, 1998; Jacob, 1971; Weitzer, 1999, 2000), which suggest that the dynamics shaping officers' perceptions of such spaces are more complex. 
Citizen perception studies generally have offered some indirect evidence of how officers' perceptions of race and policing may vary by neighborhood. These studies typically have found that residents' perceptions of policing differ across and within neighborhoods, and that race and class are associated with such neighborhood-level variation (Holmes, 1998; Jacob, 1971; Weitzer, 1999, 2000). These findings suggest that police perceptions of racial profiling also should differ between and within neighborhoods that vary by race and class.

Some citizen perception studies have provided greater insight into the relationship between officers' perceptions and the neighborhoods that they patrol by examining role of constituency groups (e.g., Weitzer, 1999, 2000). These studies suggest that how officers view profiling and other issues is significantly shaped by the officers' perceptions of the constituency groups that reside in a particular community, and that such groups' expectations, demands, and activism may make profiling a salient issue notwithstanding whatever policing imperatives are associated with the area. For instance, Weitzer $(1999,2000)$ found that the Black residents of neighborhoods in a lower-class tract were far more likely than the Black residents of a middle-class tract to claim that the police were engaged in proactive harassing and abusive patrolling (e.g., greater monitoring, and more stops, questioning, and arrests). Weitzer (2000) indicates that the residents of the Black middle-class tract were politically connected, well organized, and powerful professionals who "would not hesitate to complain to the authorities about police abuses" (p. 147). Most significantly, Weitzer (2000) notes that the police were aware of and paid heed to the clout of these Black middle-class residents; he cited examples of such residents who contended that the police went further to satisfy the residents of their neighborhoods in order to avoid complaints. Weitzer's (2000) findings suggest that the police are far more wary of engaging in any kind of racial profiling in a neighborhood where the residents are influential and likely to challenge perceived mistreatment by the police and hold them accountable.

Some studies examining race and policing that do not focus on citizen perceptions also point to the importance of investigating constituency groups within a community in order to ascertain whether officers rationalize/dismiss profiling concerns. For example, Duran (2009b) found aggressive anti-gang profiling of Latinos in Denver, Colorado subsided after Latino residents there organized and protested, but that similar anti-gang profiling continued unabated in Ogden, Utah because there was a powerful White residential neighborhood watch group that encouraged such profiling and because there was no organized opposition/activism on the part of Ogden's Latino residents. Barlow and Barlow (2002) reported on an officer who contended that the police are more likely to proactively stop and arrest Blacks in order to please wealthier residents who request (or are likely to request) such stops even in the absence of any crime-related problem in these residents' neighborhoods. Like citizen perception studies, these latter studies suggest the possibility that police may exhibit concern for racial profiling notwithstanding a larger imperative (e.g., combating high crime) to engage in such profiling, or may rationalize/dismiss racial profiling even where there is no larger imperative. 
Building on the aforementioned studies that identify communal constituency pressures on police as well as studies that highlight the importance of imperatives that officers associate with particular spaces, the current study seeks to better understand the influence of communal contexts on how officers perceive and respond to the issue of racial profiling. This study investigates officers' profilingrelated perceptions and patrolling practices in three suburban towns that vary in terms of demographics, constituencies, and spatial configurations and intends to identify whether and how profiling concerns are salient across communities. Moreover, this investigation will assist in identifying the communal features that contribute to the salience of profiling concerns and act as a constraint on officers' patrolling of racial minorities.

\section{Data and methods}

The data upon which this article is based were principally gathered through a series of ethnographic interviews and observations that I conducted during the course of 52 approximately four-hour ridealongs with patrol officers during varied shifts, days, and patrol districts in the three suburban municipalities of Coretown, Longwood, and Middleboro 4 in a northeastern state between July, 2006 and December, 2006. There were 18 ride-alongs totaling 73 hours in Coretown, 17 in Longwood totaling 72 hours; 16 of the ride-alongs totaling 66 hours were in Middleboro. Each ride-along was with a different officer. In addition to the 52 interviews conducted during the ride-alongs, I carried out a shorter, 30 to 45 minute follow-up interview with each of the 52 officers in a private room at their respective police stations on a subsequent date. The officers interviewed in the three towns were representative of the three towns' disproportionately White and male officer corps. $\underline{5}$ Sixteen of the 18 officers interviewed in Coretown were White, and all were male. Sixteen of the 18 officers interviewed in Longwood were White, and 17 were male. Thirteen of the 16 officers interviewed in Middleboro were White, and 15 were male.

Unlike quantitative methodologies, ethnographic studies help "to answer the questions of why and how" (Markowitz, 2001, p. 12), and provide a means of determining how social actors make sense of, organize, and attach meanings to people and places within their social worlds (Orbuch, 1997). By examining the meanings that actors assign to phenomena within their specific, work-related cultural and social milieu (Spradley, 1979), ethnographic methods allow for the discovery of how officers cognitively develop understandings of the various people they serve and organize such understandings into social group schemata. Consistent with the central characteristics of an ethnography, the site of the patrol car out in the community provided a natural work-related setting that was most conducive to developing an understanding of how officers perceive and interpret the issue of racial profiling (Nurani, 2008). Moreover, conducting interviews during the course of four hour ride-alongs afforded ample opportunity to establish rapport with officers and provided a secure, comfortable environment in which officers were more likely to provide candid responses. The setting of the ride-along also afforded the opportunity to compare the officers' interview accounts to their actual practices, allowed 
for a firsthand assessment of both how officers schematically interpreted and classified people in the field, and how such accounts compared with actual patrolling practices.

To learn more about officers' attitudes about racial profiling and whether potential accusations of profiling acted as a constraint on their patrolling of racial minorities, I asked officers general questions relating to their awareness of and concern about racial profiling and specific questions about any concerns or challenges they had in patrolling specific, different racial groups in specific spaces (see Appendix I). While the former line of questioning did not specify any particular racial groups, the latter line of questioning specifically focused on officers' patrolling of Blacks, Latinos, and Asians in several prominent, highly patrolled parts of town. Asking officers' about their patrolling of Blacks, Latinos, and Asians in key spaces provided an indirect way of gauging whether any thoughts relating to racial profiling were salient in particular spaces.

In order to produce interview notes as close to verbatim as possible, I amended my shorthand notes during every period in which the officer exited the patrol car to handle a particular matter or when there was a break (e.g., a dinner break). Within an hour after completing each ride-along, I expounded on the notes by reading them into a tape recorder rather than transcribing them by hand. This afforded me a quicker means of creating a record of what was said and a better vehicle for recreating officers' statements. I later transcribed these audio-taped notes into text for purposes of analysis. Informal follow-up interviews on a subsequent visit provided an opportunity to clarify any ambiguities in the ride-along interview notes.

The analysis of my interview and field notes was in accordance with the steps set forth by Spradley (1979). I searched the text for cultural symbols (native terms that officers used to signify practices) and then sought out relationships among such symbols to identify symbolic categories or domains; this domain analysis led to the identification of larger themes that appeared across several domains (Spradley 1979). The analysis process was carried out inductively at multiple stages throughout the data collection process, and concepts, categories, and themes were revised as emergent, iterative products that eventually led to the formation of a grounded theory (Charmaz, 2006; Spradley, 1979). In addition to manifest content analyses of what officers stated, inferences were made in the interpretation of some of the interview data in order to best elaborate on the tacit meanings that officers conveyed and to tie officers' statements to themes (Charmaz, 2006). For instance, while some of the officers' statements about powerful residents did not expressly indicate direct influence on officers' policing, it was clear from the context of the officers' other responses and clarifying remarks that these statements related to the theme of resident/ constituency influence.

In analyzing my empirical data I employed a manual filing method of coding described by Lofland and Lofland (1995). Consistent with this method, I devised a list of codes for the cultural symbols, domains, and themes that I identified, marked these codes in the margins of copies of the field notes and then 
cutup the coded copies and placed the cut up strips into folders corresponding to each code. I then arranged and rearranged the coded strips in ways that were most logically consistent with my emergent theory at each iteration of the analysis.

\section{Research site selections: Choosing the towns and police departments}

In order to discern whether or not officers' perceptions regarding profiling vary across communities, it is imperative to study patrol officers in at least two towns as part of a comparative ethnography (Sullivan, 1989). Comparative ethnography provides an opportunity to assess how the particular communal context in which officers work may shape officers' profiling-related perceptions. Akin to Jacob's (1971) and Weitzer's $(1999,2000)$ studies which examined citizens' perceptions in three different neighborhoods, focusing on three towns provides an even greater opportunity for assessing both between and within-town variation in officers' profiling related perceptions.

Coretown, Longwood, and Middleboro were selected in part because these were among the handful of towns in which police chiefs granted access to do ride-alongs. A standard letter was sent to police chiefs of 50 towns with a population between 20,000 and 40,000 that were within a 50-mile radius of the researcher. Access was granted to do ride-alongs in the three respective towns following an interview with each town's police chief.

Like the three neighborhoods that varied by race and class in Jacob's $(1971)$ and Weitzer's $(1999,2000)$ citizen perception studies, Coretown, Longwood, and Middleboro were specifically selected for this study as research sites because their demographic and spatial variations allowed for the opportunity to ascertain whether and how race, class, and space shape officers' perceptions across and within towns. Coretown is predominantly White (94\%), whereas Longwood and Middleboro have White majorities but some racial diversity (see Table 1). Blacks make up approximately $23 \%$ of the residents in Longwood and 33\% of the residents in Middleboro, whereas Latinos make up $15 \%$ of the residents in Longwood. Whites control local government in Coretown and Longwood, but Blacks and Whites share control over local government in Middleboro. Residents in both Coretown and Middleboro are largely middle- to upper-middle-class, whereas Longwood residents are largely working- and lower-middleclass (see Table 1). Middleboro's Black population is divided between poor and working-class residents who mostly live in the largely segregated southeastern section of town, and middle- and upper-middleclass residents who live in integrated neighborhoods throughout much of the rest of the town. Longwood's Black and Latino population is largely working-class and spatially segregated. Longwood's Black residents are clustered in the northeastern section of town, $\underline{6}$ whereas Whites and Latinos are clustered in the northwestern and southern parts of town respectively.

Although Coretown has a small percentage of residents of color, most of whom are Black (4.5\%), it has several key visitor spaces that attract racial minorities. Coretown is home to a large county college, 
Orion County College, which brings in several thousand students on any given day while school is in session, and close to three-quarters of these students are non-resident racial minorities. An alternative high school that serves nearly 200 , mostly non-resident, disproportionately Black and Latino students, is also situated in Coretown. While there are few Latino residents in both Coretown and Middleboro, both towns have large commercial districts in which disproportionate percentage of Latinos are employed. In addition, all three towns are in close proximity to towns with substantial poorer Black and Latino populations. These demographic and spatial features made Coretown, Longwood, and Middleboro fruitful settings for assessing whether concerns of racial profiling were salient for officers.

Table 1. Select race and class features of Coretown, Longwood, and Middleboro

\begin{tabular}{|c|c|c|c|c|}
\hline Town & \multicolumn{2}{|c|}{ Racial makeup } & Median income & $\%$ below poverty level \\
\hline \multirow[t]{3}{*}{ Coretown } & White & $94 \%$ & $\$ 76,300$ & $2.5 \%$ \\
\hline & Black & $4.5 \%$ & & \\
\hline & Latino & $0.9 \%$ & & \\
\hline \multirow[t]{3}{*}{ Longwood } & White & $66 \%$ & & $6.4 \%$ \\
\hline & Black & $23 \%$ & $\$ 46,300$ & \\
\hline & Latino & $15 \%$ & & \\
\hline \multirow[t]{3}{*}{ Middleboro } & White & $59.8 \%$ & & $5.6 \%$ \\
\hline & Black & $33 \%$ & $\$ 74,900$ & \\
\hline & Latino & $3 \%$ & & \\
\hline
\end{tabular}

Another consideration in selecting Coretown, Longwood, and Middleboro was their respective police departments' emphasis on traffic enforcement. Preliminary interviews with the chiefs and captains in the three towns' police departments revealed that while traffic enforcement was a top priority in Coretown, it was not a high priority in either Longwood or Middleboro. As of 2006, Coretown had the highest rate of tickets issued for traffic violations in Orion County, whereas Longwood had the second lowest. Middleboro had close to the lowest rate of tickets issued in Edward County. Given that traffic 
enforcement has been at the center of the issue of racial profiling, the varying degrees of traffic enforcement in the three towns made these towns conducive sites for assessing the impact of racial profiling on officers' cognition and patrolling practices.

Coretown, Longwood, and Middleboro also were chosen because of their police departments' organizational similarity, which fostered similar channels of community influence. The three departments had basically the same set of bureaus and divisions, rank structure, and size and number of patrol districts. Patrol practices including shifts, patrol assignments and rotations, and officers' tasks, responsibilities, and discretion were also strikingly similar. Officers patrolled alone in each town, which allowed for unfiltered interactions with the community. Each department's funding and contracts were authorized by a town council, suggesting that citizens in all three towns had similar avenues of influence over the police department. Finally, the three departments apparently shared a service orientation by which the police sought to identify and satisfy the demands of the community (Wilson, 1968). Such shared organizational features made it more likely that any differences in how officers thought about and responded to the issue of racial profiling would be a product of communal, rather than organizational, variation.

In addition, Coretown, Longwood, and Middleboro were selected as research sites because of the similar backgrounds of their police officers, which makes communal influences more salient. The majority of officers were not only similar in terms of race (White) and gender (male), but also in terms of social class (lower-middle class), childhood residence (grew up in same region), educational background (approximately two-thirds were college graduates), and professional socialization (all graduated from the same police academy). Officers' socialization within the same geographic region minimized the possibility that regional differences might affect how officers understood and approached policing. It was likely that the officers in the three departments had largely internalized similar ideas about race, ethnicity, class, and criminality while growing up, and that these officers brought a similar social group schema with them when they began working. In sum, the selection of three structurally and culturally similar departments afforded an opportunity to assess how environmental features of the towns, rather than background and organizational factors, conditioned officers' perceptions of racial profiling.

\section{Findings}

\section{Coretown officers' accounts of racial profiling and patrolling of racial minorities}

Coretown officers expressed a great deal of concern about how their patrolling practices might be perceived by others as profiling. However, such profiling-related concerns were qualified by both race and space (see Table 2). Officers only expressly referenced "Blacks" when discussing profiling 
concerns, suggesting such concerns were limited to the patrolling of Blacks. For instance, a White Coretown officer stated:

You just try to do your job and the color of the driver shouldn't matter, you know, you're just doing your job. But you still gotta be careful So I pull over a Black, say, who's speeding. What are people gonna say? "Oh, he was speeding?" No, they're gonna say, "What are you doing stopping a Black guy?"

Coretown officers' interchangeable use of the terms minority and Black or African-American when discussing profiling, and their express reference to Blacks and Latinos when discussing non-profilingrelated issues, further signify that officers' profiling concerns were limited to Blacks.

Table 2. Profiling concerns and practices in Coretown, Longwood, and Middleboro

\begin{tabular}{|c|c|c|c|c|}
\hline Town & $\begin{array}{l}\text { Concern about } \\
\text { profiling }\end{array}$ & $\begin{array}{l}\text { Racially selective } \\
\text { concern }\end{array}$ & $\begin{array}{l}\text { Spatially selective } \\
\text { concern }\end{array}$ & Aggressive patrolling \\
\hline Coretown & Yes & Yes, only for Blacks & Yes & $\begin{array}{l}\text { Yes for Blacks in } \\
\text { some spaces, \& yes } \\
\text { for Latinos in all } \\
\text { spaces. }\end{array}$ \\
\hline Longwood & No & Not applicable & Not applicable & $\begin{array}{l}\text { Yes for Blacks in } \\
\text { some spaces, \& no for } \\
\text { Latinos in all spaces. }\end{array}$ \\
\hline Middleboro & Yes & No & No & $\begin{array}{l}\text { Yes for Blacks in } \\
\text { some spaces, \& no for } \\
\text { Latinos in all spaces. }\end{array}$ \\
\hline
\end{tabular}

Officers' apparent racially selective concern about profiling also was reflected by racially skewed traffic enforcement patterns. Those whom officers defined as Latino were most likely to be stopped and ticketed. Of the observed motorists stopped (129 in total) and ticketed (60 in total), Latinos were more than twice as likely than Blacks to be stopped (48 Latinos versus 20 Blacks), and more than three times as likely to be ticketed (37 Latinos versus 12 Blacks).?

Although Coretown officers expressed concerns relating to the profiling of Blacks, such concerns were spatially qualified. Officers conveyed a high degree of concern about how their patrolling of Blacks might be perceived in some spaces and seemingly showed no concern in others. In particular, officers 
only voiced profiling-related concerns when discussing their patrolling of Blacks on Newman and Summer Avenues, the town's two main east-west roads, and within the town's central commercial district. For instance, a White Coretown officer stated the following while conducting traffic enforcement on Summer Avenue:

I do most of my traffic enforcement here and on Newman. I try to treat everybody the same, but I just worry sometimes about how it would look I think twice about pulling somebody over if they're Black. And unless it's something flagrant, I just hold back.

Coretown officers' spatially qualified concerns regarding their patrolling of Blacks were starkly reflected in their stop and ticketing practices during the course of the ride-alongs. Blacks constituted only $5.1 \%$ of those stopped ( 4 out of 78 ) and $2.7 \%$ of those ticketed ( 1 out of 37 ) along Newman and Summer Avenues and within the central commercial district, but represented 39\% of those stopped ( 16 out of 41 ) and $47.8 \%$ of those ticketed (11 out of 23 ) along the roads leading to and from an alternative high school and a county college. In contrast, Latinos were disproportionately stopped and ticketed at high rates in both sets of spaces.

Coretown officers' profiling-related concerns about Blacks along Newman and Summer Avenues and within the central commercial district were linked with several communal features. The town's demographic makeup - notably, its relatively large White population (94\%) and its relatively small Black population (4.5\%) - was a key communal feature that officers exclusively referenced in these spaces. Officers suggested that the issue of racial profiling became salient in these spaces against Coretown's White demographic backdrop. For instance, in explaining his concerns relating to profiling on Newman Avenue, a White Coretown officer remarked:

I mean, no one likes to admit it, but this is a White town. Yeah, there's a few Blacks scattered here and there, but it's still a White town You got mostly White people, and you're stopping Black people, I mean, c'mon, that's not gonna look right.

Besides the town's demographic make-up, the interests of the town's White business and civic leaders were particularly salient for officers in these Coretown spaces. Officers described how the town's business and civic leaders had raised a significant amount of money through several bond issues to improve the town's central commercial district, which was part of a larger effort to upgrade the town's regional status and compete with the nearby town of Windham. When discussing their patrolling of Blacks in this commercial district, as well as along Newman and Summer Avenues, both of which cut through this district, officers emphasized that the town's business and civic leaders were concerned about avoiding any publicity that might sully the town's reputation. In particular, officers cited how accusations of racial profiling might tarnish the town's image, and in turn, upset the town's leaders. For instance, a White Coretown officer commented: 
A lotta people have pumped a lotta money into this downtown. They've got a lot invested here. The last thing they wanna see is some story in the Norville Gazette about cops harassing Blacks in Coretown. They don't want this place to be seen as some racist, backwards kinda place They don't want anything that's gonna give the town a black eye.

In addition to the aforementioned communal features, officers' assumptions about what racial minorities potentially were doing along Newman and Summer Avenues and within the commercial district appeared to condition officers' concerns about profiling. More specifically, officers' assessments of racial minorities in these latter spaces hinged on whether members of these largely non-resident racial groups would be staying in town for extended periods of time and causing trouble. A White Coretown officer alluded to this when discussing patrolling of non-residents, "You get a lot of people who cut through here, and some of them ... don't really have any other reason than to come here and hang out and cause trouble."

Coretown officers made no references to Blacks causing trouble when discussing patrolling along Newman and Summer Avenues and within the central commercial district . Officers saw non-resident Blacks in these spaces as passing through town rather than staying for extended periods of time and interacting with others. For instance, in discussing his patrolling of Blacks in these spaces, a White Coretown officer stated:

Why would you profile someone, I mean, if they are just passing through town. They're not bothering anyone. What would that accomplish? The only thing that would do is get everybody saying, "What are you doing? Really, c'mon." It would be obvious to everyone that we had no reason to be pulling over Blacks.

As reflected by these remarks, Coretown officers believed that any targeting of Blacks in these spaces would appear gratuitous to potential observers because Blacks posed no discernible threat. As a result, others' potential profiling-related criticisms became salient to the officers.

In contrast to Coretown officers' apparent heightened concern about how people might perceive officers' policing of Blacks along Newman and Summer Avenues and within the commercial district, Coretown officers expressed seemingly no concern regarding potential scrutiny as they patrolled Latinos in these spaces. Officers routinely described Latinos as being either a threat or a nuisance. Unlike the negligible Black residential population, the dearth of Latino Coretown residents (less than 1\%) did not appear to contribute to any concerns about how profiling might be perceived against Coretown's White demographic backdrop. Moreover, even though Coretown officers explained that many non-resident Latinos worked in establishments in the commercial district, these officers paradoxically did not see Latinos as being legitimately present in this space or along the connecting spaces of Newman and Summer Avenues. 
Any potential legitimacy that Latinos may have had from their status as workers was eclipsed by officers' stereotypical images of Latinos as drug runners, thieves, and gang members. Officers made numerous assertions about Latinos trafficking illegal drugs between two nearby towns, Elmwood and Piedmont. Officers also frequently made reference to Latino workers' petty crimes such as shoplifting, implying that these workers' jobs were a front for criminal activity. For instance, after stopping a Latino male dishwasher, a White Coretown officer stated: "You never know with these guys. Yeah, he says he works as a dishwasher, but what is he really up to. I bet a lot of these guys are doing more than just washing dishes." Moreover, Coretown officers saw the commercial district as a networking site for Latino criminality. A White Coretown officer stated the following about Latinos, "They like to powwow with their hombres You've got Mexicans from all over working down there; that's where they meet up, that's where they wheel and deal."

In addition to presenting Latinos as a threat, Coretown officers also characterized Latinos as a nuisance. This latter characterization was based on a group of Latino male day laborers who congregated near the commercial district's train station. Officers saw this group, which numbered near 100 during morning hours, as engaging in nuisance-related offenses such as blocking vehicular and pedestrian traffic, urinating in public, and littering. These perceptions bolstered officers' view that Latinos were not legitimately present. In sum, officers saw non-resident Latinos, unlike nonresident Blacks, as staying in town for extended periods of time and causing trouble.

In marked contrast to their stated profiling-related concerns regarding patrolling Blacks along Newman and Summer Avenues and in the commercial district, Coretown officers voiced no such concerns in other heavily-patrolled spaces. In particular, officers expressed no apparent concern about profiling accusations when discussing their patrolling of Blacks at the Alternative High School (AHS), which serves nearly two hundred youths who are unable to function in traditional classrooms and are from around Orion County, and at Orion County College (OCC), which is a year-round community college that serves 9,000 students, most of whom hail from other towns in Orion County, and the northsouth roads leading to and from AHS and OCC. Rather, officers' accounts of their patrolling of Blacks in these latter spaces were dominated by references to criminal threat. In contrast to their patrolling accounts of Blacks and Latinos along Newman and Summer Avenues and within the commercial district, officers' patrolling accounts of Blacks and Latinos in the spaces associated with AHS and OCC were indistinguishable. Moreover, officers routinely made joint references to Blacks and Latinos when discussing their patrolling in these latter spaces, but carefully distinguished Blacks and Latinos when discussing their patrolling in other spaces. For Coretown officers, the potential threat posed by both Latinos and Blacks eclipsed any profiling-related concerns in spaces associated with AHS and OCC. Coretown officers' seeming lack of concern about racial profiling in the spaces associated with AHS and OCC were reflected in Blacks' substantially higher stop and ticketing rates in these spaces. Blacks 
not only were far more likely to be stopped and ticketed in the spaces associated with AHS and OCC, but were stopped and ticketed at higher rates than those of Latinos in these spaces. Officers' distinction between Blacks and Latinos appeared to vanish at AHS, OCC, and along the roads leading to and from AHS and OCC.

Coretown officers' apparent lack of concern about racial profiling and their aggressive patrolling of both Blacks and Latinos in spaces associated with AHS and OCC were derived from officers' view of AHS and OCC as Black and Latino non-resident spaces ensconced within White residential areas. AHS and OCC served as a triggering mechanism for pathologies officers associated with criminogenic, lowerincome Black and Latino communities in the surrounding area. The presence of Blacks and Latinos at or near AHS and OCC activated officers' thoughts of these problematic Black and Latino communities. Coretown officers' discussions of AHS and OCC students invariably included some reference to drug and gang-related problems in Black and Latino towns such as Piedmont and Elmwood. For instance, a White Coretown officer said the following about a minor shoving match involving several AHS students. "Who knows what the hell they were fighting over. Probably somebody stole somebody else's dope. They bring that shit in from Piedmont and Elmwood and deal it over here."

Based on their numerous references to drug dealing, car theft, and gang activity, Coretown officers appeared to assume that unlike non-resident Blacks along Newman and Summer Avenues and within the commercial district, Blacks and Latinos within the vicinity of AHS and OCC were staying in town for an extended period of time to commit crimes. A White Coretown officer alluded to this when discussing non-resident Blacks and Latinos at OCC. "You've got Blacks and Hispanics from Norville, Elmwood, places like that, and they're coming here to stir the pot, you know, just cause trouble. They're not coming here for school, just to cause trouble, that's all."

In discussing their concerns about non-resident Blacks and Latinos causing trouble at or in the vicinity of AHS and OCC, officers appeared to be most worried about the possibility that these non-residents would corrupt other students, particularly White students, and would possibly detrimentally influence youth in the White residential areas in which AHS and OCC were ensconced. For instance, nearly all Coretown officers referenced an incident involving a White male AHS student from Coretown who claimed to be a member of the Crips gang. A White officer who had arrested this youth for fighting described how this youth apparently had become a Crip:

There were several kids from the alternative school who got into a big fight. One of the ones we arrested was this 16-year-old Coretown kid. I started asking him what happened, and ... he tells me that he's a Crip Apparently he'd been hanging around with some kids from Piedmont over at the alternative school who got him into that Crips thing ... I ... told him, "These kids you've been hanging with are no good." 
Through this often-recounted Crip story, officers suggested that Black and Latino non-resident AHS students were influencing vulnerable, generally good White Coretown youths to join gangs.

Similarly, officers suggested that Black and Latino non-resident drug dealers were corrupting White youths at OCC. In recounting an illegal drug distribution ring led by non-resident Blacks and Latinos in a lounge in one of OCC's main buildings, Coretown officers emphasized that they were most alarmed by the numerous White Coretown youths they had arrested for buying weed. A White Coretown officer remarked:

There were several dealers from Norville and Edgarville who had set up shop in the lounge At first we thought it was mostly Blacks and Mexicans selling to each other. Come to find out that most of the ones buying were Caucasian. [Y] ou had high school kids from Coretown buying weed over at OCC. That's when we knew that things were out of control.

Officers referenced White drug buyers at OCC, like that of the White Crip at AHS, not for the purpose of condemning White youths, but rather to emphasize how Black and Latino non-residents were preying upon such youths.

Coretown officers' spatially divergent perceptions of and approaches toward Blacks highlight the importance of communal context, perceptions of what different groups' members are doing, and space in shaping how officers think about racial profiling and go about patrolling racial minorities. In particular, the officers' radically different perceptions of and approaches toward Blacks travelling on Newman Avenue compared to that of Blacks travelling to and from AHS and OCC demonstrates how racialized assumptions about space lead to differential policing. Although many of the Black motorists travelling to AHS or OCC first traveled westward on Newman Avenue upon entering Coretown, officers' concerns about and approach toward Black motorists depended on whether these motorists stayed on Newman Avenue. If Black motorists stayed on Newman Avenue, officers viewed these motorists as harmlessly passing through town, which in turn increased the saliency of communal interests opposing the racial profiling. However, as soon as Black motorists either turned left or right off of Newman Avenue, officers saw these motorists as coming to stir the pot and cause trouble, and any potential profiling concerns were eclipsed by concerns of threat to White residents' interests. Thus, Coretown officers' apparent sensitivity to racial profiling accusations hinged upon how officers understood racial minorities' behaviors in relation to communal interests within particular spaces.

\section{Longwood officers' accounts of racial profiling and patrolling of racial minorities}

Like Coretown officers, Longwood officers viewed racial profiling as an issue solely pertaining to the patrolling of Blacks. While Longwood officers made numerous references to the term Black when discussing the issue of profiling, they never used Latino, Hispanic or any other racial terms. Moreover, 
consistent with their virtual lack of concern about and restrained patrolling of Latinos, Longwood officers did not allude to profiling when discussing Latinos. Longwood officers, like Coretown officers, saw profiling as a Black issue.

Although Longwood officers and Coretown officers similarly framed racial profiling as a Black issue, Longwood officers, in contrast to Coretown officers, expressed no apparent concern about the issue of racial profiling (see Table 2). All Longwood officers were dismissive of the possibility that their patrolling practices might be perceived by others as profiling. Most officers were dismissive in an indifferent, nonchalant way, but several officers were dismissive in a sarcastic, somewhat brash way. For instance, a White male officer remarked, "Yeah, so I stop some Blacks. What are they gonna do? Accuse me of profiling or something? Yeah, right."

In dismissing the issue of racial profiling, a majority of Longwood officers also suggested that racial profiling was a manufactured problem that deflected attention away from the reality that Blacks commit a disproportionate amount of crime. A White Longwood officer stated:

The real problem, but no one wants to admit it, is that Blacks just happen to commit a lot of crimes. Everyone points the finger at us, but we just deal with who is committing crimes ... If we stop more Blacks it's 'cause they're involved in more crime. It's that simple.

As reflected by this officer's matter-of-fact tone, Longwood officers confidently and unequivocally conveyed that racial profiling was a non-issue. Unlike Coretown officers, Longwood officers neither expressed trepidation about how others might judge their patrolling of Blacks nor exhibited any apparent defensiveness.

Longwood officers' insouciant attitude toward the issue of racial profiling appeared to be tied in part to Longwood's demographics. In explaining their disproportionate encounters with Blacks, Longwood officers suggested that it was normal for officers to have such encounters. One White Longwood officer stated the following when discussing officers' frequent interactions with Black male teens and young adults:

You know I wish I didn't have to deal with the shittums [(young Black males)]. You know, if it was up to me, I'd just stay the hell away from them ... But there's no way you can avoid 'em; they live here. You're gonna run into them whether you like it or not.

For Longwood officers, Longwood's sizable (23\%) Black population made encounters with Blacks seem routine, and, in turn, precluded officers from viewing such encounters as profiling.

While demographics may have helped to normalize encounters between Longwood officers and Blacks, these officers' lack of concern about racial profiling appeared to be mainly connected to their 
perceptions of Longwood's dominant White residents' interests. Longwood officers suggested that vocal, active members of this dominant, powerful constituency group of White residents, which constituted two-thirds of the town's population, expected officers to aggressively, proactively patrol Blacks in White lower-middleclass neighborhoods in the large northwestern part of town, as well as along the western border of the town's working-class and poor Black section in the northeastern part of town. In particular, Longwood officers discussed White residents' expectation that officers would move along Black students walking home from Longwood High School (LHS) after 3 P.M. on school days. For example, a White Longwood officer remarked:

The people who live over here on Maple [Street], they go nuts if somebody tramples on their flowers or leaves candy wrappers on their lawn. Now the ones who're at work, they can't prove it's Black kids from the high school, but when they complain, you know who they mean. But the ones who are home, they're like ready to pounce if you don't keep these kids moving. There's one lady that's always flaggin' us down, telling us that they are cuttin' through her yard, messin' up the place, hangin' socks on her trellis ...

In discussing these White residents' expectations regarding officers' patrolling of Blacks, Longwood officers emphasized the high probability that the former would complain to superior officers or town officials if officers did not disperse Black youths from White neighborhoods. For instance, a White Longwood officer stated the following when discussing Black high school students congregating in the streets in White neighborhoods:

You know that if you don't do anything, you know Mrs. Jones down on Maple Street, or Mrs. Jackson down on Oak Street, you know they're gonna be on the phone with the Lieutenant. There was a lady who wrote a letter to the Chief saying that some Blacks from the high school were blocking the sidewalk and harassin' her kids on the way back from school ... We put a stop to that You don't want any headaches.

As this officer revealed, Longwood officers saw White residents as potential complainants who wielded leverage over officers. Accordingly, Longwood officers felt compelled to proactively police Blacks in order to avoid the wrath of these residents.

Longwood officers' concerns of appeasing powerful White constituents was reflected by officers' aggressive, proactive patrolling of Black pedestrians in groups of three or more in White northwestern neighborhoods. Longwood officers routinely motioned to and verbally confronted groups of Black youths in these neighborhoods. - In particular, officers regularly monitored and confronted groups of Black students walking home from LHS on school days between 3 and 5 P.M. The apparent goal of this racially selective patrolling, which officers described as herding, was to informally escort Black students out of White neighborhoods. Officers routinely engaged in what they described as a cat and 
mouse game with Black student pedestrians, repeatedly reprimanding these students for loitering, walking in the street, or crossing residents' properties. For instance, after spotting a group of five Black male and three Black female students who were standing in the street about a block and a half to the southeast of LHS, a White male Longwood officer pulled up his patrol car and stated from the window of car, “You can't have a block party here. It's time to take the show on the road. Now let's go. ... Let's go guys."

Longwood officers' aggressive, proactive patrolling of Blacks, particularly younger Black males, along northern and western perimeter area of District 4 in the northeastern part of town, which officers' referred to as the Black section of town and the target area, also appeared to be fueled in part by officers' concerns about appeasing powerful White residents. Officers not only explained that their disproportionate patrolling of this Black perimeter area was due to the area's alleged high rate of illegal drug and other low-level criminal activity, but also because White residents in the northwestern part of Longwood were concerned about such activity spilling over into their neighborhoods. For instance, while discussing officers' patrolling of the target area, a White Longwood officer linked up such patrolling with the concerns of residents of the White Bright Acre section in northwestern Longwood:

You've got drug dealers, some gangster wannabes, hustlers, you name it, over here. That's why it's called the target area. We do the best we can to keep things under control, but there's only so much you can do; we just don't have the manpower. We just try to make sure that shit doesn't spill over into Bright Acre. They would go ballistic if it did They don't want the 'hood in their neighborhoods.

Longwood officers' concerns about powerful White residents appeared to provide officers with a license to racially profile Blacks, as either part of an effort to keep Blacks out of White neighborhoods or contain Blacks to Black neighborhoods. Such concerns seemed to preclude officers from seeing such patrolling as profiling or feeling conflicted about it.

In addition to the perceived pressures from White residents, officers' patrolling of Blacks, particularly in White spaces, appeared to be shaped by Longwood's residential and school-related spatial configurations. Longwood's largely racially segregated neighborhoods, coupled with assumptions about how neighborhood schools shaped friendship patterns, seemed to contribute to officers' sense that Blacks were out of place in White neighborhoods. Officers explained that as a result of residential patterns, few Black and White children attended elementary and middle schools together. Consequently, these children's friendship networks were solidified along racial lines by the time these children reached Longwood's racially integrated high school. In turn, officers did not expect Black and White youth to be mingling outside of school. A White Longwood officer described these links between 
residential spaces, schooling, and race while discussing officers' patrolling in White northwestern neighborhoods:

The Blacks they mostly keep to the Blacks, and the Whites mostly keep to the Whites. They don't really have much to do with each other. I think a lot of that is due to the schools. They don't go to school with each other, I mean before high school, so how do you expect them to get to know each other and be friends? ... So, if you see Black kid in Bright Acre, your first thought is, "What is he doing here?" It's not being racist, you just don't expect kids from District 4 hanging out here. Just like you don't see kids from Bright Acre over in District 4. They just don't have much to do with each other. You see it outside of the high school. The Whites stand with the Whites, and the Blacks stand with the Blacks. That's just the way it is.

As this officer's comments suggest, assumptions about space and social patterns not only contributed to officers' sense that Blacks were out of place in White neighborhoods, but that officers' selective monitoring of Blacks in these neighborhoods was legitimate, rational policing rather than illegitimate, irrational profiling.

While communal features such as powerful constituents' interests and residential and schooling spatial patterns appeared to significantly contribute to how officers viewed Blacks in particular spaces, such views also seemed to be contingent on what officers perceived Blacks as doing. Like those of Coretown officers, Longwood officers' determinations of whether people were out of place were not simply based on the presence of those people in certain racially marked spaces, but rather depended on what officers perceived those people as doing in those spaces. Although Longwood officers aggressively patrolled Blacks in White residential spaces, such patrolling was generally limited to Black pedestrians. Officers generally paid little attention to Black motorists in such spaces, unless these motorists stopped and lingered. Like Coretown officers, Longwood officers appeared to view Blacks who were passing through White spaces as legitimately present. Officers assumed that Black motorists' fleeting presence in such spaces, unlike that of Black pedestrians, precluded the possibility of engaging in behaviors that might upset White residents.

Officers' assumptions about what Blacks were doing in relation to communal interests appeared to affect officers' patrolling of Blacks inside the perimeter of Longwood's northeastern Black section and within commercial spaces. Longwood officers generally ignored Blacks in these spaces because they expected Blacks to occupy these spaces and did not perceive Blacks as engaging in activities that threatened the interests of Longwood's dominant White group. Unlike Coretown officers' restrained patrolling of Blacks in some Coretown spaces, Longtown officers' restrained patrolling of Blacks in the latter Longwood spaces did not appear to be driven by any concerns about racial profiling. While the overall communal context of Coretown seemed to constrain officers' patrolling of Blacks in some spaces, the overall communal context of Longwood appeared to provide little, if any constraint on 
officers' patrolling of Blacks. Longwood officers' apparent restraint with respect to patrolling Blacks seemed to be tied to the absence of any communal-based reasons to do so, rather than the presence of communal constraints. As the officer's comment at the beginning of this section suggests, Longwood officers gave the impression that they could target Blacks without any repercussions.

\section{Middleboro officers' accounts of racial profiling and patrolling of racial minorities}

Like Coretown officers and unlike Longwood officers, Middleboro officers expressed a great deal of concern about possible accusations of racial profiling (see Table 2). However, Middleboro officers' concerns were broader than those of Coretown officers in two respects. First, Middleboro officers' profiling-related concerns were not limited to Blacks. Although Middleboro officers, like both Coretown and Longwood officers, generally seemed to equate the issue of racial profiling with Blacks, Middleboro officers voiced concerns about how others might perceive their patrolling of Latinos. 9 Second, Middleboro officers' concerns about profiling were not spatially qualified. Unlike Coretown officers, Middleboro appeared concerned about possible profiling accusations in all spaces.

Middleboro and Coretown officers both seemed to be defensive when discussing the issue of racial profiling, but Middleboro officers' defensiveness was much more apparent. Middleboro officers were far more likely than Coretown officers to suggest that their jobs were potentially at risk because of profiling accusations. A White Middleboro officer remarked, "You've got to watch your step. A buddy of mine nearly lost his job after some people complained that he was targeting minorities."

Middleboro officers also expressed greater resentment and frustration when discussing the issue of profiling. In particular, Middleboro officers were more likely than Coretown officers to indicate that potential profiling accusations hampered officers' ability to do effective police work. For example, a White Middleboro officer stated, "It's hard. You try to do your job, but you're worrying that if I do my job, somebody might turn around and call me a racist."

Middleboro's officers' broader and deeper concerns about profiling appeared to be linked mainly to their desire to avoid incurring the wrath of Middleboro's dominant, highly organized, and vocal informal collaboration between Black and White middle-to upper-middle class residents. Officers indicated the members of this liberal and pro-civil rights collaboration generally assumed that the police unfairly targeted or harassed minorities. With a combination of trepidation and resentment, Middleboro officers indicated that these residents actively monitored the police's handling of racial minorities, and were quick to protest or complain about the police to various media, such as the local newspaper or the town's unofficial website, or to rights-based organizations such as the NAACP and ACLU.

In particular, officers noted that members of this informal collaboration routinely intervened on behalf of poorer Blacks from Middleboro's largely segregated southeastern section; over half of the 
officers referenced the response of wealthier Black Middleboro residents to an incident in which a White Middleboro officer mistakenly arrested a poor Black southeastern male he thought fit the description of a suspect wanted for several robberies. The arresting officer remarked:

Not long after I started here a couple of years ago I got into trouble. We'd had a bunch of robberies down over at Lakeview Plaza, and we were looking for a Black guy with an orange hat and a white shirt. I arrested a guy over by Magnolia [Street] who fit the suspect's description. It turned out it wasn't him. Well people here went berserk, especially the Blacks. It was like World War III. Not so much with the ones from the south end, but people with money. There was this Black lawyer, who organized some kind of rally. They had articles in the Middleboro Times about it, he was saying this was like apartheid. I mean, give me a break.

In recounting this and other incidents, Middleboro officers suggested that wealthier Black residents perceived the arrests of any Blacks, including the poorest Blacks in the Norman and Monroe Streets area, as being profiling or harassment. Middleboro officers attributed this perception to wealthier Blacks' personalizing every incident involving a Black person.

Although Middleboro officers repeatedly expressed concerns about upsetting the town's wealthier Black residents, approximately two-thirds of the officers' profiling-related concerns pertained to White residents. All officers described over half of the town's White residents as vigilant hawks who ardently defended and came to the aid of Blacks, especially Black children, during encounters between the police and Blacks. For instance, an Asian Middleboro officer recounted an incident in which a middle-aged White woman swiftly intervened on behalf of a group of Black youth whom officers were questioning in relation to an alleged fight that had taken place:

You'd think that just the Blacks would be the ones who care about the Blacks, but here, the thing that's different about this place is the Whites. One time we got this call that there's a group of Black kids fighting over on Willow [Street], and one of them has a gun. We had seven cars that responded. It turns out that it was just some kids screwin' around with a painted toy gun. The boy with the gun got scraped by one of the police cars, but he jumped up. Well, as soon we got there, a bunch of people in the area came over right away and start in with, "Why'd you hit him with your car?" "Why do you need so many police?" "Why can't you just let them play?" I'll never forget, in the middle of this whole thing, this one White lady says, "What are you doing to these kids?" Then she turned to a couple of them and said, "Are you okay, honey?" Meaning like we were hurting them or something ... Before she left, but she tells us that we'd better not harass these boys, and that she'd be watching us. Can you believe that, that she'd be watching us!

Against this backdrop of seemingly omnipresent monitoring and likely intervention by powerful White and Black residents, concerns about racial profiling were highly salient for Middleboro officers 
whenever they encountered racial minorities and contributed to a cautious, restrained approach to patrolling racial minorities in most spaces.

In a more indirect way, Middleboro officers' heightened sensitivity to profiling accusations and cautious patrolling approach appeared to be tied to perceptions of residential and school-related spatial patterns. Officers indicated that not only were many of the Middleboro's neighborhoods racially integrated, but that the town's schooling patterns enhanced racial integration in most spaces throughout town. Officers explained that Middleboro used a random selection process for assigning students to elementary and middle schools, which in turn normalized and legitimized the presence of people of any race or class in virtually any space. A White Middleboro described this school-related legitimization:

The ways the schools are set up here, anybody could be anywhere. It's not like you can say, "What is he doing in the neighborhood, or what is she doing in the neighborhood." No, I mean, even if you can tell somebody's not from the neighborhood, you can't assume, "What are you doing here." They might be visiting a friend, picking up their child, you never know. Because the kids all go to school with each other, they've got friends all over the place. It's not like where I grew up, where you were pretty much just friends with whoever lived in your neighborhood. No, here, you expect kids to be hanging out outside of their neighborhoods.

As this officer suggested, the random assignment of students starting at the beginning of their school careers not only conditioned officers to expect that children and parents or caretakers of different races and classes would be in various parts of the town related to school-related business and activities, but that children would develop friends in other parts of the town and socialize with them. As a result, Middleboro officers, unlike Longwood officers, did not consider it odd to see children or adults of different races and classes in residential neighborhoods that were relatively homogeneous in terms of race and/or class. Children might be visiting friends in such neighborhoods, or their parents or caretakers might be dropping them off or picking them up. Such socially-defined spatial patterns, coupled with officers' perceptions of Middleboro's dominant Black/White resident collaboration, made Middleboro officers highly conscious of and concerned about how others perceived their patrolling of racial minorities.

Notwithstanding Middleboro officers' apparent high degree of concern regarding potential profiling accusations, Middleboro officers aggressively patrolled some Blacks in the vicinity of an upscale shopping area located on the western part of the town's large southern commercial district and along the southernmost point of Omega Road, a major cross-town street. In patrolling the shopping area, Middleboro officers spent a disproportionate amount of time monitoring Blacks who, based on dress and demeanor, appeared to be from Middleboro's lower-class Norman and Monroe Streets area in the southeastern part of town. This was the only space in Middleboro where officers suggested that some 
Blacks were out of place. A White male officer stated, "If you spot someone from Norman and Monroe over here, you know that they're not window shopping. If they want to hang out, they gotta find some other place."

For Middleboro officers, Norman and Monroe Street Blacks lacked the in-place legitimacy of middleclass and wealthy Blacks (perceived as patrons of the area's establishments) and Latinos (seen as workers in such establishments).

The vicinity of the upscale shopping center also was only place officers confronted any Black pedestrians during the course of the ride-a-longs. In particular, officers regularly confronted younger Blacks, especially males, along the shopping center's eastern border. The bulk of these confrontations occurred on the sidewalk in front of a place called the Chicken Shack, which was located a block and a half east of the shopping center. Officers claimed that the Chicken Shack was a front for drug activity and routinely dispersed the group of mostly Black male teens and young adults who congregated outside of it in an eastward direction away from the shopping center.

Middleboro's officers' aggressive patrolling of Norman and Monroe Street Blacks within the vicinity of the upscale shopping area appeared to be exclusively driven by concerns of appeasing business owners. Officers indicated that over the past ten years or so, store and restaurant owners had repeatedly complained about groups of Black youths congregating in front of or near their establishments. Officers noted that these complainants claimed that these groups of Black youths loitered, made excessive noise, littered, and sometimes intimidated or harassed patrons. A Latina Middleboro officer described the complaints made by the owner (Jose) of the Epicurian Café, which was located on the eastern fringe of the upscale shopping area:

Every time I see Jose he tells me about these punks from the Norman and Monroe who hang out in front of his café, making all kinds of noise, throwing their trash on the sidewalk, and basically actin' a fool. He's always tellin' them they have to move, and when they don't, he chases them down the block ... We try to help him out as much as we can.

Unlike Coretown officers' aggressive patrolling of Blacks and Latinos within the vicinity of AHS and OCC, Middleboro officers' aggressive patrolling of Blacks within the vicinity of the upscale shopping area was characterized by a high degree of ambivalence. In contrast to Coretown officers, Middleboro officers appeared to weigh competing interests and to be constantly mindful of the issue of racial profiling. Although Middleboro officers appeared to assign more weight to the interests of business owners than those of the town's informal collaboration of Black and White residents, concerns about the latter left Middleboro officers feeling conflicted and uneasy. 
Middleboro officers also engaged in aggressive patrolling of Blacks at the southernmost part of Omega Road, which was a principal entry point for nonresidents. Officers both expressly and implicitly conveyed that they chose this point on Omega Road in order to monitor and possibly intercept suspicious non-residents from disproportionately Black, poor and working-class towns like Omega, Edgarville, and Winslow. A White male Middleboro officer indicated that he chose to do traffic enforcement at this location because it would enable him to prevent "outsiders" from bringing their crime-related problems such as illegal drug dealing into Middleboro. This officer said:

This is good spot to do radar 'cause you've got people coming and going from all the different towns. If you're gonna catch something, you're gonna catch it here. And if you do, it's a good way to tell outsiders that they're not welcome to bring their dirt $\underline{10}$ here.

As in the upscale shopping area, Middleboro officers appeared to be ambivalent about the disproportionate traffic enforcement that they conducted along this part of Omega Road. While officers spoke of concerns about outsiders coming into Middleboro to engage in crimes, officers simultaneously spoke of possible complaints of profiling from liberal residents. However, officers also noted that even liberal residents were somewhat conflicted about the issue of disproportionately monitoring drivers entering Middleboro via Omega Road. For instance, a White Middleboro officer described residents' ambivalence as follows:

They don't want us profiling, but they don't won't crime in their neighborhoods either. The reality is, whether they like to admit it or not, is that most of the ones breaking into homes and stealing cars are Blacks from Omega, Edgarville, Norville. They know that, but if we try to do something about it, it's like we're the bad guys.

The salience of concerns about crime, coupled with perceived ambivalence of even Middleboro's liberal collaboration of Black and White residents, appeared to enable Middleboro officers to target Black motorists entering town on Omega Road despite competing concerns regarding profiling.

While resident group pressures and spatial arrangements appeared to play in significant role in conditioning Middleboro officers' concerns regarding racial profiling, the town's racial demographics did not. As in Longwood, officers in Middleboro did not view encounters with Blacks to be unusual due to the presence of a sizable Black population. However, despite the normality of encounters with Blacks, Middleboro officers, unlike Longwood officers, were highly concerned about possible profiling accusations. This suggests that the presence of a substantial minority population, in itself, is not sufficient to temper concerns about profiling. 


\section{Discussion}

The findings from Coretown, Longwood, and Middleboro show that officers think about and respond to the issue of racial profiling in variable ways across and within communities. Communally-shaped concerns about racial profiling contribute to differences in how officers patrol a particular racial minority group in different spatial contexts. Unlike the rather uniform, dismissive view of profiling documented by the few prior studies examining officers' profiling-related perceptions, the variable profiling-related concerns exhibited by officers in the current study suggest that officers possess complex racial schemas that can be constituted by different sets of seemingly contradictory information about race and policing. It appears that prior studies of officers' perceptions of profiling have not sufficiently examined the communal contexts in which officers are ensconced. The variability of officers' racial schemas and patrolling of racial minorities further suggest that theoretical perspectives that predict the uniform patrolling of racial minorities may miss critical inter- and intracommunal differences in officers' patrolling of particular racial groups. For instance, this variability of profiling concerns is inconsistent with the conflict theory-based racial threat thesis, which argues that criminal justice authorities exercise coercive control over all racial minorities to neutralize any perceived threats to dominant White group interests (Weitzer \& Tuch, 2006).

These findings also provide a number of theoretical insights into the communal features/processes that shape how officers think about racial profiling and approach racial minorities. Consistent with conflict theory (e.g., Chambliss \& Seidman, 1971), officers appear to be particularly attuned to the interests of powerful resident/constituency groups within their towns of employment. However, in contrast to the racial threat variant of conflict theory, officers' attentiveness to such interests may lead to greater concern about racial profiling and less aggressive patrolling of racial minorities in some communal contexts. Coretown officers' elevated concerns about racial profiling and restrained patrolling of Blacks in some spaces appeared to be due in part to the officers' fears of upsetting business owners, whereas Middleboro officers' heightened concerns about racial profiling and restrained patrolling of all racial minorities in most spaces seemed to be principally driven by fears of incurring the wrath of powerful Black and White residents. We should expect officers to engage in a more restrained type of patrolling with respect to a particular racial group where officers perceive that a powerful community resident group is opposed in some way to the targeting of that group.

While officers in some communities, like those in Longwood, may encounter one set of resident/constituency pressures that are salient and predominant in all communal spaces, officers in other communities, like those in Coretown and Middleboro, may face conflicting resident/constituency pressures. In the latter communities, the saliency of particular resident/constituency interests affects both officers' degree of restraint in patrolling racial minorities as well the degree to which officers' feel conflicted about such patrolling. If officers, like those in Middleboro in the vicinity of the upscale shopping area, are confronted with two or more sets of similarly salient resident/constituency 
pressures, officers will tailor their patrolling to the most salient set, but will feel conflicted. If one set of resident/constituency pressures is highly salient compared to that of others, officers will accommodate those pressures without feeling conflicted (as in Coretown).

In addition to resident/constituency pressures, overall spatial arrangements appear to shape the saliency of profiling concerns and the patrolling racial minorities. Consistent with prior research that has demonstrated that racial profiling is most likely to occur when officers perceive racial minorities as being out of place in White spaces (Bates \& Fasenfest, 2005; Meehan \& Ponder, 2002), the findings from the three towns show that profiling-related concerns are likely to be more prominent and might constrain officers' patrolling of racial minorities where arrangements of spaces confer in place legitimacy to racial minorities. For instance, the arrangement of schools in Middleboro appeared to confer in place legitimacy to the Norman and Monroe Street Blacks in all residential spaces, but this in place legitimacy did not extend to the upscale shopping area.

However, the findings from Coretown in particular suggest that having some ostensibly legitimate connection to a particular space is not necessarily sufficient to generate or sustain concerns about profiling. Rather, the Coretown findings show that officers' perceptions of what racial minorities are doing in particular communal spaces is critical for predicting whether profiling concerns will be prominent. In contrast to Loewen (2005), who found that police did not profile Blacks who worked in a White town because the officers saw Blacks as being in town for a work-related purpose, the findings here show that merely being in town for a legitimate purpose is not enough. Profiling concerns in Coretown only appeared to be salient if officers perceived racial minorities as engaging in activities consistent with the meanings attached to work- or school-related spaces. Notwithstanding Latinos connections to work-related spaces in the commercial district, and Blacks and Latinos connections to the school-related spaces in and around OCC and AHS, Coretown officers appeared to exhibit no concerns about profiling these respective groups in these spaces due to assumptions that these groups were causing trouble.

While the findings from Coretown suggest that the absence of racial minorities may make profilingrelated concerns more salient, the conflicting findings from Longwood and Middleboro suggest that the presence of racial minorities does not necessarily make such concerns less prominent. Although Middleboro's fairly large Black minority population contributed to the likelihood of encounters between officers and Blacks, officers exhibited a high degree of concern regarding how they patrolled Blacks in most spaces. This finding suggests that resident/constituency pressures and the meanings associated with spatial arrangements play a more significant role than demographic information in conditioning how officers think about and respond to profiling-related concerns.

The findings herein provide an initial step toward identifying communal features/processes that shape the salience of profiling-related concerns and affect officers' patrolling of racial minority groups. 
While the context-specific nature of ethnographic research precludes generalizing the findings from any one town to predict what particular features may be salient in another specific town, the patterns of between-town and within-town variation found in this study suggest that there are some aspects of communities that contribute to officers' variable understanding and articulation of racial profiling. Accordingly, a close examination of a particular community is warranted in order to best ascertain how officers within that community view and respond to the issue of racial profiling. In order to develop a better understanding of potential influential communal features, future research should investigate multiple communities that are diverse in terms of spatial characteristics and resident demographics and constituencies.

Another potential limitation of the ethnographic findings is the trustworthiness of officers' responses. In light of the highly controversial and sensitive nature of the topic of racial profiling, it is possible that officers may provide responses that are politically correct or "what they think the researcher would like to hear" (Nurani, 2008, p. 446). Again, the pattern of between-town variation in officers' responses implies that this was not a significant issue in the extant study, as similar politically correct responses would have been found across towns. The inclusion of multiple sites in this study increased the external validity of this study, not because each respective site's findings confirmed the findings of the others (Nurani, 2008), but rather because it afforded the possibility to establish variability in responses across towns.

In addition, the nature of interview setting and the relationship between the researcher and the respondents also suggest that the officers' responses generally were forthright and trustworthy. The natural setting of the patrol car appeared to assist in eliciting candid responses from officers, as it helped to make officers think less of themselves as research subjects (Nurani, 2008). Moreover, the similar status characteristics of the researcher and the majority of officer respondents appeared to facilitate candid responses. Officers generally appeared very comfortable interacting with the researcher, whose White, male status characteristics were consonant with those of the majority of officers in each town.

While similar status characteristics of the officer samples from the three respective towns assisted in minimizing the potential influence of individual-level variables on officers' responses, it is possible that more racially diverse samples of officers may reveal that individual-level variables play a more influential role than communal features in shaping officers' perceptions of racial profiling; it is possible that officers of color, like the majority of officers in Barlow and Barlow's (2002) all-Black officer sample, may exhibit greater concerns than White officers about racial profiling, and that these concerns will be largely consistent across towns. However, since few officers of color in the extant study provided responses that were similar to those of their fellow officers in each of the three 
respective towns, it appears that individual-level variables play a secondary role to structural, community-based variables.

Besides examining police departments with more racially diverse samples of officers, as well as communities that are diverse in terms of spatial characteristics and resident demographics and constituencies, future research should investigate towns that appear to differ in terms of their police organizational structures and subcultures. A comparison of towns with different police organizational structures and subcultures may demonstrate that such organizational and subcultural variables play a more central role than outside communal variables in shaping how officers think about the issue of profiling. Such diverse, future multi-site studies of officers' perceptions of profiling will not only provide a better understanding of the possible communal mechanisms that contribute to such perceptions, but also will help to clarify the respective influence that individual-level and organizational variables may have in some town contexts.

\section{Appendix}

Appendix A. Interview Guide

I. General Questions about Profiling:

1. How do you view the issue of racial profiling?

2. How much do you think about the issue of profiling?

3. Do you worry about potential accusations of profiling? When? Where? By whom?

4. How do other officers in your department view the issue of profiling?

5. How do residents in your town [of employment] appear to view the issue of profiling?

6. What complaints have been made about profiling within your town? Who has made such complaints? Were the complainants complaining about how they have been profiled or how some other group has been profiled?

II. Patrolling Racial Groups and Spaces:

1. What concerns or challenges do you face in patrolling [space $\mathrm{x}]$ ?* $^{*}\left[{ }^{*}\right.$ Repeat this question for all prominent spaces within town.]

2. What concerns or challenges do you face in patrolling Whites?

a. What concerns or challenges do you face in patrolling Whites in [space $\mathrm{x}$ ] ? [Repeat this question for all prominent spaces within town.]

3. What concerns or challenges do you face in patrolling Blacks?

a. What concerns or challenges do you face in patrolling Blacks in [space $\mathrm{x}$ ]? [Repeat this question for all prominent spaces within town.] 
4. What concerns or challenges do you face in patrolling Latinos?

a. What concerns or challenges do you face in patrolling Latinos in [space $\mathrm{x}$ ]? [Repeat this question for all prominent spaces within town.

5. What concerns or challenges do you face in patrolling Asians?

a. What concerns or challenges do you face in patrolling Asians in [space $\mathrm{x}$ ]? [Repeat this question for all prominent spaces within town.]

\section{References}

Alpert, G. P., \& Dunham, R. G. (1988). Policing multi-ethnic neighborhoods: The Miami study and findings for law enforcement in the United States. Westport, CT: Greenwood Press.

Barlow, D., \& Barlow, M. (2002). Racial profiling: A survey of African American police officers. Police Quarterly, 5, 344-358.

Bates, T, \& Fasenfest, D. (2005). Enforcement mechanisms discouraging black-American presence in suburban Detroit. International Journal of Urban and Regional Research, 29, 960-971.

Bornstein, A., Charles, S., Domingo, J., \& Solis, C. (2011). Police narratives about racial and ethnic identities on patrol. John Jay College, New York, NY, September.

Bureau of the Census. (2002). Census of population and housing. 2000 [United States] summary tape files 1 and 2.

Chambliss, W. J., \& Seidman, R. (1971). Law, order and power. Reading, MA: Addison-Wesley.

Charmaz, K. (2006). Constructing grounded theory: A practical guide through qualitative analysis.

London, England: Sage.

De Genova, N., \& Ramos-zayas, A. Y. (2003). Latino racial formations in the United States: An introduction. The Journal of Latin American Anthropology, 8, 2-17.

Duran, R. J. (2009a). Legitimated oppression: Inner-city Mexican American experiences with police gang enforcement. Journal of Contemporary Ethnography, 38, 143-168.

Duran, R. J. (2009b). Over-inclusive gang enforcement and urban resistance: A comparison between two cities. Social Justice, 36, 82-98.

Glover, K. S. (2007). Police discourse on racial profiling. Journal of Contemporary Criminal Justice, 23, 239-247. 
Goldsmith, P., Romero, M., Rubio-Goldsmith, R., Escobedo, M., \& Khoury, L. (2009). Ethno-racial profiling and state violence in a southwest barrio. Aztlán: A Journal of Chicano Studies, 34, 93-123.

Harris, D. (2002). Profiles in injustice: Why racial profiling doesn't work. New York, NY: New Press.

Heumann, M., and Cassak, L. (2007). Good cop, bad cop: Racial profiling and competing views of justice. New York, NY: Peter Lang.

Holmes, M. (1998). Perceptions of abusive police practices in a U.S.-Mexico border community. The Social Science Journal, 35, 107-118.

Jacob, H. (1971). Black and white perceptions of justice in the city. Law \& Society Review, 6, 69-90.

Lofland, J., \& Lofland, L. (1995). Analyzing social settings: A guide to qualitative observation and analysis. Belmont, CA: Wadsworth Publishing Company.

Loewen, J. W. (2005). Sundown towns: A hidden dimension of American racism. New York, NY: The New Press.

Markowitz, M. W. (2001). Theoretical explanations of the nexus between race and crime. In M. W. Markowitz \& D. D. Jones-Brown (Eds.), The system in black and white: Exploring the connections between race, crime, and justice (pp. 3-13). Westport, CT: Praeger.

Meehan, A. J., \& Ponder, M. C. (2002). Race and place: The ecology of racial profiling African American motorists. Justice Quarterly, 19, 399-430.

Miller, K. (2007). Racial profiling and postmodern society: Police responsiveness, image maintenance, and the left flank of police legitimacy. Journal of Contemporary Criminal Justice, 23, 248-262.

Nurani, L. (2008). Critical review of ethnographic approach. Jurnal Sosioteknologi, 7, 441-448.

Orbuch, T. L. (1997). People's accounts count: The sociology of accounts. Annual Review of Sociology, 23, 455-478.

Romero, M. (2006). Racial profiling and immigration law enforcement: Rounding up of usual suspects in the Latino community. Critical Sociology, 32, 447-473.

Satzewich, V., \& Shaffir, W. (2009). Racism versus professionalism: Claims and counter-claims about racial profiling. Canadian Journal of Criminology and Criminal Justice, 51, 199-226.

Smith, D., Visher, C., \& Davidson, L. (1984). Equity and discretionary justice: The influence of race on police arrest decisions. Journal of Criminal Law and Criminology, 75, 234-249. 
Solis, C., Portillos, E., \& Brunson, R. (2009). Latino youths' experiences with and perceptions of involuntary police encounters. Annals of the American Academy of Political and Social Science, 623, 39-51.

Spradley, J. P. (1979). The ethnographic interview. Fort Worth, Tx: Harcourt Brace Jovanovich.

Sullivan, M. L. (1989). “Getting paid”: Youth crime and work in the inner city. Ithaca, NY: Cornell University Press.

Vera Sanchez, C. \& Adams, E. (2011). Sacrificed on the altar of public safety: The policing of Latino and African American youth. Journal of Contemporary Criminal Justice, 27, 322-341.

Warren, P. Y., \& Farrell, A. (2009). The environmental context of racial profiling. The Annals of the American Academy, 623, 52-63.

Warren, P. Y., \& Tomaskovic-Devey, D. (2009). Racial profiling and searches: Did the politics of racial profiling change police behavior? Criminology \& Public Policy, 8, 343-368.

Weitzer, R. (1999). Citizen perceptions of police misconduct: Race and neighborhood context. Justice Quarterly, 16, 819-846.

Weitzer, R. (2000). Racialized policing: Residents' perceptions in three neighborhoods. Law E Society Review, 34, 129-155.

Weitzer, R., \& Tuch, S.A. (2006). Race and policing in America: Conflict and reform. New York, NY: Cambridge University Press.

Werthman, C., \& Piliavin, I. 1967. Gang members and the police. In D. Bordua (Ed.), The police: Six sociological essays (pp. 56-98). New York, NY: Wiley.

Wilson, J. Q. (1968). Varieties of police behavior. Cambridge, MA: Harvard University Press.

\section{Contributors}

Paul Reck is an assistant professor of sociology at Ramapo College. Dr. Reck has a Ph.D. in Sociology from Rutgers University, and a J.D. from City University of New York. Dr. Reck's research and teaching focuses on social constructions of crime and deviance, and the various societal mechanisms that contribute to racial and class stratification both within and outside of the criminal justice system in the United States.

\section{Footnotes}

1. Racial profiling represents a type of aggressive policing. Aggressive policing encompasses proactive surveillance, stops, questioning, ticketing, searches, and arrests. $€$ 
2. Several studies have found that salience of racial profiling as an issue has constrained officers' patrolling of racial minorities, but do not provide any clear evidence regarding how officers themselves think about the issue. Warren and Tomaskovic-Devey (2009) found that local media accounts of racial profiling and racial profiling legislation in North Carolina significantly contributed to a reduction in the proportion of searches of Black motorists relative to those of White motorists by officers of the North Carolina State Highway Patrol's drug interdiction team. Similarly, Warren and Farrell (2009) found that increased media coverage of racial profiling and change in the police organizational leadership led to a reduction in the disparity of searches of Black motorists relative to those of White motorists by officers in Providence, Rhode Island. However, in both of these studies, it appears that officers were responding to the directives and sanctions of superiors, rather than directly to political discussions that they heard via the media and the legislature. $\bullet$

3. Consistent with De Genova and Ramos-zayas (2003), I treat "Latinos" as a "race group." Officers discussed "Latinos" as a racial grouping distinct from that of Blacks and Whites.

4. Coretown, Longwood, and Middleboro are pseudonyms. Pseudonyms are also used for all references to places within these communities. $\subseteq$

5. The majority of officers in each town were White (92\% in Coretown, $91 \%$ in Longwood, and $84 \%$ in Middleboro) and male (96\% in Coretown, $98 \%$ in Longwood, and 92\% in Middleboro).

6. The clustering of most of Longwood's Black population in the northeastern part of town appeared to augment officers' perceptions of the size of Longwood's Black population. $\triangleq$

7. Coretown officers estimated that $75 \%$ to $90 \%$ of motorists traveling in Coretown were White. $\triangleq$

8. Officers did not mention White residents' concerns about Latino students, and the only time officers' motioned to or confronted Latino students was when they were in the company of a group of Black students. $ヒ$

9. Officers did not mention White residents' concerns about Latino students, and the only time officers' motioned to or confronted Latino students was when they were in the company of a group of Black students. $€$

10. This officer defined "dirt" as meaning drug dealing and other crime- and gang-related activity. $\boxminus$ 